Available online at www.refaad.com

VMPH 1(3) ; 2020 : 127-131

Research Article

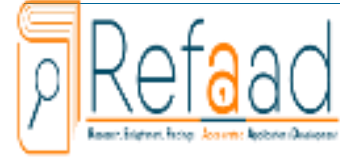

www.refaad.com
Veterinary Medicine and Public Health Journal (VMPH)

Journal Homepage: https://www.refaad.com/views/vmph/home.aspx

ISSN : 2707-7195(Online) 2707-7187(Print)

\title{
Prevalence of gastrointestinal nematodes of cattle slaughtered at the lugbe slaughter slab, federal capital territory (FCT), Abuja
}

\section{Onyekanihu Amaka Liliana, Arowolo Olajoke Bukolab, Tags Zacharia Samc, Opara Nwachukwu Maxwelld, Mohammed Balarabe Rabiu ${ }^{\text {** }}$}

aDepartment of Veterinary Parasitology and Entomology, Faculty of Veterinary Medicine, University of Abuja, P.M.B 117, Federal Capital Territory, Abuja, Nigeria. Email: amakalilian4j@yahoo.com

bepartment of Veterinary Parasitology and Entomology, Faculty of Veterinary Medicine, University of Abuja, P.M.B 117, Federal Capital Territory, Abuja, Nigeria. Email: benbukky78@yahoo.com

'Department of Veterinary Anatomy, Faculty of Veterinary Medicine, University of Abuja, P.M.B 117, Federal Capital Territory, Abuja, Nigeria. Email: zachariatags@yahoo.com

dDepartment of Veterinary Parasitology and Entomology, Faculty of Veterinary Medicine, University of Abuja, P.M.B 117, Federal Capital Territory, Abuja, Nigeria. Email: opara.maxwell@gmail.com

eDepartment of Veterinary Parasitology and Entomology, Faculty of Veterinary Medicine, University of Abuja, P.M.B 117, Federal Capital Territory, Abuja, Nigeria. Email: balarabemohammed161@yahoo.co.uk

*Corresponding author: Mohammed Balarabe Rabiu (balarabemohammed161@yahoo.co.uk)

How to cite this article: Lilian. O.A. et al. Prevalence of gastrointestinal nematodes of cattle slaughtered at the lugbe slaughter slab, federal capital territory (FCT), Abuja. Veterinary Medicine and Public Health Journal 1(3); 2020: 127-131.

\begin{abstract}
Gastrointestinal nematodes (GIN) are known to be major constraint to cattle well-being and productive performance worldwide. Their prevalence in Abuja Municipal Area Council (AMAC), Abuja is not well studied. This study was carried out to investigate the prevalence of nematodes of cattle slaughtered at the Lugbe slaughter slab of the Federal Capital Territory, Abuja, Nigeria. Between the months of November 2017 and March 2018, a total of two hundred (200) faecal samples were collected and analysed using direct and floatation methods. Of these, 66 (33\%) were infected with gastrointestinal nematode parasites. Five (5) genera of nematodes were identified; Ascaris spp, 24 (36.4\%); Strongyles spp, 20 (30.3\%); Trichostrongylus spp, 10 (15.2\%); Nematodirus spp, $8(12.1 \%)$ and Trichuris spp, 4 (6.1\%). Mixed infection of these parasites involved oocysts which accounted for $27(13.5 \%)$ and was statistically significant $(\mathrm{p}<0.05)$. In relation to sex, prevalence in female $(55 \%)$ were higher than male (28\%), while adults had higher prevalence $(36.4 \%)$ than in the young (29.9\%). The prevalence rate of nematode parasite ova was higher in both female and young cattle than the male and adult cattle, respectively. There was no statistical difference $(\mathrm{P}>0.05)$ between the age of cattle and prevalence of nematode parasites. Statistical results showed no association $(\mathrm{P}>0.05)$ between the nematode parasite ova and the months which the cattle were slaughtered. However, there was an association $(\mathrm{P}<0.5)$ between the prevalence of nematode parasites and the sex of the cattle. Our findings revealed that there were GIN in the screened animals. Appropriate nematode parasites control measures using novel and sustainable approaches including sustainable integrated parasite management (SIPM) have been recommended.
\end{abstract}

Keywords: Lugbe; Nematodes; Nigeria; Floatation; Sedimentation.

\section{Introduction}

Cattle production in Nigeria with a population of about 14 million, is the largest in the west African region, and over $90 \%$ of this population is concentrated in the northern part of the country (Lawal-Adebowale 2012; Presicce 2020). Cattle is a major source of protein and served during ceremonies; their dung also serve as manure for agricultural productions and even as survival kit for the nomadic people (Olubukola et al. 2014; Imo 2017). The growth, physical development and well being of cattle in Nigeria is often hampererd by 
helminthic infections including nematodes (Karshima et al. 2018; Sanda et al. 2019).

Gastrointestinal nematodes (GIN) pose a great burden on the health of animals leading to significant production and economic losses to the animals and farmers, respectively (Charlier et al. 2015). The most common nematodes present in cattle in Nigeria include; Haemonchus spp, Oesophagostomum radiatum, Nematodirus spp, Ostertagia spp, Toxocara spp, Ascaris spp, Trichuris spp, Trichostrongylus spp and Strongylodes spp (Chiejina 1994; Dogo et al. 2017; Singh and Bello 2017). Of these, Ostertagia spp and Haemonchus spp are considered the most pathogenic and economically important nematode parasites of cattle worldwide (Chiejina 1994). The variation in the transmission patterns of the gastrointestinal nematodes is dependent on the particular climate in the geographic location and environment they exist (Roeber et al. 2013).

Previous studies reveled significant evidence on the impact of nematode infections on the health and productivity of cattle in Nigeria (Jegede et al. 2013; Agbajelola et al. 2015; Sylvia et al. 2015; Afolabi et al. 2017; Lemy and Egwunyenga 2017; Dogo et al. 2017 and Yohanna et al. 2019). However, to the best of our knowledge, there are no published studies investigating the prevalence of nematode infections among cattle slaughtered at Lugbe slaughter slab, Abuja Municipal Area Council (AMAC), Nigeria. Providing information on nematode among slaughtered cattle would assist in the design of an effective strategic control measures to improve health conditions and productivity in cattle. This study therefore investigated the prevalence of gastrointestinal nematodes of cattle slaughtered at the Lugbe slaughter slab, Federal Capital Territory (FCT), Abuja.

\section{Materials and methods}

\section{Study area}

This study was carried out in Lugbe, Abuja Municipal Area Council (AMAC) of the Federal Capital Territory, Abuja. Lugbe is located between latitudes $0855^{\prime} \mathrm{N}$ to $0900 \mathrm{~N}$ and longitudes $0719^{\prime} \mathrm{E}$ to $0726^{\prime}$ covering an area of about $50 \mathrm{~km}$ of the Greenwich meridian. The relative humidity varies in the area due to seasonal variations. The temperature ranges between $30-37^{\circ} \mathrm{C}$ annually with the highest temperature experienced in the month of March/April and with a mean total rainfall approximately 1,650 mm per annum (NPC 2006).

\section{Study population}

Two hundred (200) cattle including males and females were sampled and examined between the months of November 2017 and March 2018. Visual observations of the cattle were made and were categorized into two major body conditions involving poor and good (Nicolson and Butterworth 1986). Poor body conditioned cattle had prominent dorsal spines pointed to the individual visible transverse processes whereas the good body conditioned cattle had flesh cover easily seen in critical areas and transverse processes were not felt. Sex (whether male or female determined by their genitalia), age of the animals was estimated by their dentition (Abegaz and Awgichew 2009) classifying $>2$ years as young while cattle $<2$ years of age were classified as adults. There was no proper information on the breeds and history of deworming.

\section{Sample collection}

Faecal samples were collected from the rectum of randomly selected cattle at the point of slaughter. All collected faeces were stored in plastic containers containing about $2 \mathrm{ml}$ of prepared $10 \%$ formalin added to avoid hatching of the eggs, labeled appropriately prior to transportation to the Parasitology laboratory, Faculty of Veterinary Medicine, University of Abuja. On each of the animals screened, parameters such as body condition score, breed and sex were recorded.

\section{Faecal examination}

Faecal samples were examined using direct smear and standard floatation techniques using saturated solution of sodium chloride $(\mathrm{NaCl})$, prepared with a specific gravity of 1.20 was used, in recovering the eggs/ova of the parasite. All eggs were identified on the basis of their morphological features as described by (Soulby 1986).

\section{Data analysis}

Data obtained from this study were tabulated accordingly for easy assessment. All analyses were done using Statistical Package for Social Sciences (SPSS) version 16. They were subjected to descriptive statistical analysis using simple percentages in determining the prevalence rates in the different parasites (nematode ova), months, sex, age, and body conditions score was analyzed using Chi-square statistical test, the level of significance was set at $\mathrm{P}<0.05$.

\section{Results}

Out of the 200 cattle examined, 66 (33.0\%) of them were infected with GIN. The highest prevalence was recorded against Ascaris spp 24 (36.4\%), followed by Strongylus spp, 20 (30.3\%), while the least prevalence was recorded against the genus Trichuris spp 4(6.1\%) (Table 1). 
Table (1): Overall prevalence of nematode parasites in cattle slaughtered at the Lugbe slaughter slab in relation to months $(\mathrm{n}=200)$

\begin{tabular}{|c|c|c|c|c|c|c|}
\hline & $\begin{array}{l}\text { Nov. } \\
(\mathrm{N}= \\
40)\end{array}$ & $\begin{array}{l}\text { Dec. } \\
(\mathrm{N}= \\
50)\end{array}$ & $\begin{array}{l}\text { Jan. } \\
(\mathrm{N}= \\
40)\end{array}$ & $\begin{array}{c}\text { Feb. } \\
(\mathrm{N}= \\
40)\end{array}$ & $\begin{array}{c}\text { Mar. } \\
(\mathrm{N}= \\
30)\end{array}$ & $\begin{array}{l}\text { Total } \\
(\mathrm{N}= \\
200)\end{array}$ \\
\hline Genera & $\begin{array}{l}\text { No. (\%) } \\
\text { infected }\end{array}$ & $\begin{array}{l}\text { No. (\%) } \\
\text { infected }\end{array}$ & $\begin{array}{l}\text { No. (\%) } \\
\text { infected }\end{array}$ & $\begin{array}{l}\text { No. (\%) } \\
\text { infected }\end{array}$ & $\begin{array}{l}\text { No. (\%) } \\
\text { infected }\end{array}$ & $\begin{array}{l}\text { No. (\%) } \\
\text { infected }\end{array}$ \\
\hline $\begin{array}{l}\text { Trichostrongylus } \\
\text { spp }\end{array}$ & $\begin{array}{c}5 \\
(29.4)\end{array}$ & $\begin{array}{c}2 \\
(15.4)\end{array}$ & $\begin{array}{c}2 \\
(12.5)\end{array}$ & $0(0)$ & $1(7.7)$ & $\begin{array}{c}10 \\
(15.2)\end{array}$ \\
\hline Strongyles larva & $\begin{array}{c}5 \\
(29.4)\end{array}$ & $\begin{array}{c}5 \\
(76.9)\end{array}$ & $\begin{array}{c}6 \\
(37.5)\end{array}$ & $0(0)$ & $\begin{array}{c}4 \\
(30.8) \\
\end{array}$ & $\begin{array}{c}20 \\
(30.3)\end{array}$ \\
\hline $\begin{array}{l}\text { Nematodirus } \\
\text { spp }\end{array}$ & $\begin{array}{c}2 \\
(11.8)\end{array}$ & $0(0)$ & $\begin{array}{c}2 \\
(12.5)\end{array}$ & $\begin{array}{c}3 \\
(42.9)\end{array}$ & $1(7.7)$ & $\begin{array}{c}8 \\
(12.1)\end{array}$ \\
\hline Ascaris spp & $\begin{array}{c}4 \\
(23.5) \\
\end{array}$ & $\begin{array}{c}6 \\
(46.2) \\
\end{array}$ & $\begin{array}{c}5 \\
(31.2) \\
\end{array}$ & $\begin{array}{c}2 \\
(28.6) \\
\end{array}$ & $\begin{array}{c}7 \\
(53.8) \\
\end{array}$ & $\begin{array}{c}24 \\
(36.4) \\
\end{array}$ \\
\hline Trichuris spp & $1(5.9)$ & $0(0)$ & $1(6.3)$ & $\begin{array}{c}2 \\
(28.6) \\
\end{array}$ & $0(0)$ & $4(6.1)$ \\
\hline Total & $\begin{array}{c}17 \\
(25.8)\end{array}$ & $\begin{array}{c}13 \\
(19.7)\end{array}$ & $\begin{array}{c}16 \\
(25.4)\end{array}$ & $\begin{array}{c}7 \\
(10.6)\end{array}$ & $\begin{array}{c}13 \\
(19.7)\end{array}$ & $\begin{array}{c}66 \\
(33.0)\end{array}$ \\
\hline
\end{tabular}

The highest prevalence was recorded in the month of November (25.8\%), January, (25.4\%) and $19.7 \%$ for the months of march and December. The least occurrence of nematode infection was in the month of February. However, there was no association between the prevalence of nematode parasites and the months in which cattle were slaughtered $(\mathrm{P}>0.05)$ (Table 2$)$.

Table (2): Monthly distribution in relation to body condition of cattle slaughtered at the Lugbe slaughter slab

\begin{tabular}{|l|c|c|c|c|c|}
\hline \multicolumn{1}{|c|}{ Month } & $\begin{array}{c}\text { Number } \\
\text { sampled }\end{array}$ & $\begin{array}{c}\text { Number wit } \\
\text { h poor } \\
\text { Nourishmen } \\
\mathbf{t}\end{array}$ & $\begin{array}{c}\text { Frequency } \\
\text { (\%) }\end{array}$ & $\begin{array}{c}\text { Number with } \\
\text { good } \\
\text { nourishment }\end{array}$ & $\begin{array}{c}\text { Frequency } \\
\text { (\%) }\end{array}$ \\
\hline November & 40 & 4 & 2 & 36 & 18 \\
\hline December & 50 & 4 & 2 & 46 & 23 \\
\hline January & 40 & 3 & 1.5 & 37 & 18.5 \\
\hline February & 40 & 7 & 3.5 & 33 & 16.5 \\
\hline March & 30 & 6 & 3 & 24 & 12 \\
\hline Total & $\mathbf{2 0 0}$ & $\mathbf{2 4}$ & $\mathbf{1 2}$ & $\mathbf{1 7 6}$ & $\mathbf{8 8}$ \\
\hline
\end{tabular}

Table 3 revealed that of the 200 faecal samples taken from the cattle, 158 were males while 42 were females. The overall positive male samples were 45 with a prevalence of $28.5 \%$ while the overall positive female samples were 23 with a prevalence of $54.8 \%$. Therefore the prevalence of nematode parasite in relation to sex in the study was found to be higher in female than male. The statistical analysis however showed an association between the sex of the cattle and the prevalence of nematode parasites $(\mathrm{P}<0.05)$. In relation to age, $36.4 \%$ of the infected $>2$ years while $29.9 \%$ were $<2$ years of age. There was no association between the age of the cattle and the prevalence of nematode parasites $(\mathrm{P}$ $>0.05$ ). Twenty- four (24), $12 \%$ had poor body conditions while the ones with good body conditions were (176) $88 \%$.
Table (3): Overall prevalence of nematode parasites in cattle slaughtered at the Lugbe slaughter lab in relation to months

\begin{tabular}{|c|c|c|c|c|c|}
\hline Variable & Category & $\begin{array}{c}\text { Number } \\
\text { examined }\end{array}$ & $\begin{array}{c}\text { Number } \\
\text { positive }\end{array}$ & $\begin{array}{c}\text { Number } \\
\text { negative }\end{array}$ & \%Prevalence \\
\hline Sex & Male & 158 & 45 & 113 & 28.5 \\
\hline & Female & 42 & 23 & 19 & 54.8 \\
\hline & Total & $\mathbf{2 0 0}$ & $\mathbf{6 8}$ & $\mathbf{1 3 2}$ & $\mathbf{3 2}$ \\
\hline Age & & & & & \\
\hline & $>2$ years & 134 & 40 & 94 & 26.9 \\
\hline & $<2$ years & 66 & 24 & 42 & 36.4 \\
\hline $\begin{array}{l}\text { Body } \\
\text { condition } \\
\text { score }\end{array}$ & $\begin{array}{c}\text { Total } \\
\text { body } \\
\text { condition }\end{array}$ & $\mathbf{2 0 0}$ & $\mathbf{6 6}$ & $\mathbf{1 3 6}$ & $\mathbf{3 4}$ \\
\hline & $\begin{array}{c}\text { Poor } \\
\text { body } \\
\text { condition }\end{array}$ & 200 & 176 & 24 & 12 \\
\hline
\end{tabular}

There was an association between the sex of the cattle and the prevalence of nematode parasites $(\mathrm{P}<0.05)$.

\section{Discussions}

The 5 genera of gastrointestinal nematodes (GIN) obtained from the 200 cattle sampled at the Lugbe slaughter slab include; Trichostrongyloides spp, Strongylus spp, Nematodirus spp, Ascaris spp and Trichostrongyloides spp. Ascaris spp had the highest prevalence rate of infection while $\mathrm{T}$ Trichuris spp had the lowest. The overall results of this study revealed that there is a moderate prevalence $66(33.0 \%)$ of gastrointestinal nematodes.

However, the month of November had the highest nematode prevalence rate of $25.8 \%$, followed by January (25.4\%), March and December both had the prevalence rates of (19.7\%), respectively. The least prevalence of nematode parasites was recorded against the month of February 7 (10.6\%). This is contrary to the findings of Yohanna et al. (2012) who discovered significant difference with nematode parasites ova in the different months of sampling. This result is similar to the works carried out in Ibadan, South Western, Nigeria (Olubukola et al. 2014) and Abraka, Delta State, Nigeria (Lemy and Egwunyenga 2017).The findings in this study have been consistent with Biu et al. (2009). This is very alarming because the period of sampling in this present study which is dry season (November to March) does not support optimal development of eggs and infective larval stages of these parasites..

Furthermore, poor sanitation in the abattoir can also contribute to this prevalence. The correlation therefore between sanitation and prevalence was reported by Anene et al. 1994 and Fakae 1990. It was observed that there is little or no veterinary inspection carried out to ensure the cleanliness of this abattoir. Hence, the cattle owners and butchers can afford to slaughter any type of cattle not minding their health condition and the implication of slaughtering such infected cattle for sale to the populace. 
Another reason for nematodes prevalence in these cattle could be that they are supplied by the Fulani herdsmen who subject these cattle to free grazing especially along the river banks which has also been supported by the works of Ajayi et al. 1986 and Fabiyi 1973.

This study also revealed that female cattle (54.8\%) had higher prevalence of nematode parasite than the male cattle (28.5\%). This could be that the female are being reared basically for reproduction and are only brought in for slaughter at the abattoir in cases of infection or as a result of old age and inability to reproduce further. In other words, the physiological condition of the female animals during reproduction process could be a major contributory factor (Urquhart et al. 1996, Valcarcel and Romero 1990). The results of this study are consistent with previous researchers (Anene 1994 ; Fakae 1990; Biu et al. 2009; Jegede et al. 2015).

Another significant finding in this study was that young cattle had higher infection than the adult. Under normal circumstance young cattle cannot be brought into the slaughter slab for slaughter except on diseased conditions. This explains why the young cattle brought into the abattoir for slaughter are more infected than the adult cattle. This concurs with the findings of Yohanna et al. 2012 and Biu et al. (2009) also recorded significant difference with nematode parasites ova accross the different age groups revealing infections were higher in the young than the adults groups. This however contrasted the findings of Bashir et al. (2012) who reported no significant difference in the animals in relation to age.

This study also revealed that out of the 200 cattle sampled, 24 had poor body conditions with a prevalence of $12 \%$, while 176 had good body conditions with a prevalence of $88 \%$. This remarkable difference could be attributed to either or non-existence of favorable environmental factors because these cattle were brought in from different locations of the country for slaughter at this abattoir. Furthermore, management system of these animals from different parts of the country could also be accountable for this variation in body conditions. This work therefore provided information on the prevalence rate of infection of nematodes in these cattle and the possible zoonotic significance. In order to mitigate this parasitic infection, comprehensive parasite control program, pasture management, and environmental sanitation in cattle and public health awareness are recommended. New innovative schemes using novel and sustainable approaches referred to as sustainable integrated parasite management (sIPM) are also under consideration.

Acknowledgements: The authors thank all those who have been associated with this project especially personnel at the Lugbe Slaughter slab, Abuja Municipal Area Council (AMAC), Abuja for providing us with the enabling environment to successfully conduct this research.

Conflict of interest: Authors declare no conflict of interest.

\section{References:}

[1] Abegaz, S. \& Awgichew, K. (2009). "Estimation of weights and age of sheep and goats. Technical Bulletin No 23. Ethiopian sheep and goat productivity improvement programmed (ESGPIP)". United State Agency for International development (USAID). 14.

[2] Afolabi, O. J., Simon-Oke, I. A. \& Ademiloye, O. A. (2017). "Gastro-intestinal parasites of bovine in Akure abattoirs, Nigeria". J Entomol Zool Sts. 5:13811384.

[3] Agbajelola, V.I., Falohun, O.O., Jolayemi, E.B. \& Obebe, 0.0. (2015). "Prevalence of intestinal helminths and protozoa parasites of ruminants in Minna, North Central, Nigeria". IOSR J Agric Vet Sci. 8: 62-67.

[4] Anene, B. M., Onyekwodiri, E.O., Chime, A. B. \&Anika, S.M. (1994). "Gastrointestinal parasites in ruminants of south eastern Nigeria". Vet J Small Rum Ani. 13: 187-197.

[5] Ajayi, J.A., Adu, F.D., Asaba, M.O., Ajayi, A. \& Lamorde, A. G. (1987). "Nigerian Livestock farms". Ahmadu Bello University. Press Limited. 1: 18-21.

[6] Bashir, A.L., Ahmad, F., Chishti, M.Z. \& Tak, H. (2012). "A Survey of Gastrointestinal Helminth Parasite of Slaughtered Sheep and Goats in Ganderbal, Kashmir". Glob Vet. 8: 338-341.

[7] Biu, A.A., Maimunatu, A., Salamatu, A.I. \& Aghatu, E.T. (2009). "A feacal survey of gastrointestinal parasites of ruminants in the University of Maiduguri Research Farm". Int J Biomed Health Sci. 5: 175-17.

[8] Charlier, J., De Waele, V., Ducheyne, E., van der, Voort M., Velde, F.V. \& Claerebout, E. (2015). "Decision making on helminths in cattle: diagnostics, economics and human behaviour". Irish Vet J. 69(1): 14, https://doi.org/10.1186/s13620-016-0073-6.

[9] Chiejina, S.N. (1994). "Epidemiology of some helminth infections of domesticated animals in the tropics with emphasis on fasciolosis and parasitic gastroenteritis". In: N. Chowdhury and I. Tanada (eds), Helminthology, (Narosa Publishing House, New Delhi). $43^{\wedge} 72$

[10] Dogo, A.G., Karaye, G.P., Patrobas, M.G., Galadima, M. \& Gosomji, I. J. (2017). "Prevalence of gastrointestinal parasites and their impact in domestic animals in Vom, Nigeria". Saudi J Med Pharm Sci. 3: 211-216.

[11] Fabiyi, J. P. (1973). "Seasonal fluctuations of nematode infections in goats in the savannah belt of Nigeria". Bull Epiz Dis Afr. 21: 227-286.

[12] Fakae, B. B. (1990). "The epidemiology of helminthosis in small ruminants under the traditional husbandry systems in eastern Nigeria". Vet Res Comm. 14(5): 381- 391, https://doi.org/10.1007/bf00343216. 
[13] Imo, C. K. (2017). "The demographic implications of nomadic herdsmen and farmers clashes in Nigeria". Int J Dev Manag Rev. 12: 45-58.

[14] Jegede, O.C., Ayegba, A. A., Obeta, S.S. \& Olutayo, D.O. (2015). "Gastrointestinal parasites of sheep and goats in Gwagwalada Area Council, FCT, Abuja, Nigeria, with a reference to sex, breed and age". Alex J Vet Sci. 46(1):170 -176, https://doi.org/10.5455/ajvs.177135.

[15] Jegede, O.C., Rabiu, B.M., Obeta, S.S., Malang, S.K. \& Ejiofor, C.E. (2013). "Gastrointestinal parasites of ruminants slaughtered in Gwagwalada Abattoir, Federal Capital Territory, Abuja, Nigeria". Nig J Parasitol. 34: 55-59.

[16] Karshima, S. N., Maikai, B. V. \& Kwaga, J.K.P. (2018). "Helminths of veterinary and zoonotic importance in Nigerian ruminants: a 46-year meta-analysis (19702016) of their prevalence and distribution". Infect Dis Poverty. 7(1): 52, https://doi.org/10.1186/s40249-0180438-z.

[17] Lawal-Adebowale, 0. A. (2012). "Dynamics of ruminant livestock management in the context of the Nigerian agricultural system". Lives Prod, 4: 1-20.

[18] Lemy, E.E. \& Egwunyenga, A.O. (2017). "Prevalence of parasitic helminths from faecal samples of cattle at various abattoirs in Abraka, Delta state, Nigeria". J Ani Health Behav Sci. 1-3.

[19] National Population Commission (NPC) 'Enumerators manual', March, (2006).

[20] Nicolson, M. J. \& Butterworth, M.H. (1986). "A guide to condition scoring of Zebu cattle". International livestock centre for Africa, Addis Ababa, Ethiopia. 129.

[21] Olubukola, D.A., Emmanuel, C.U., Victor, O. A., Oyeduntan, A.S. \& Idowu, B.C. (2014). "Prevalence of gastrointestinal helminths in Slaughtered cattle in Ibadan, South-Western Nigeria". J Vet Med, Article. ID923561.

[22] Presicce, G. A. (2020). "Food Security in Cameroon and Nigeria: Animal Production and Animal
Health". Cameroon-Nigeria-Italy scientific cooperation: veterinary public health and sustainable food safety to promote "one health/one prevention". 12: 122.

[23] Roeber, F., Jex, A. R. \& Gasser, R. B. (2013). "Impact of gastrointestinal parasitic nematodes of sheep, and the role of advanced molecular tools for exploring epidemiology and drug resistance-an Australian perspective". Parasite Vector. 6(1): 153, https://doi.org/10.1186/1756-3305-6-153

[24] Sanda, M.E., Uwalaka, E. C., Idika, I.K. \& Agbaji, L.E. (2019). "Prevalence of helminths in cattle in Anyigba, Kogi state, Nigeria”. J Entomol Zool Sts, 7: 171-174.

[25] Singh, K. \& Bello, R. (2017). "A survey of gastrointestinal parasites of Bovine slaughtered at Sokoto abattoir". Spec. J Biol Sci. 3: 33-37.

[26] Soulsby, E.J.I. (1986). Helminths, Arthropods and protozoa of Domesticated Animals. 7thEdition Bailliere, Tindal, London, 136-778.

[27] Sylvia, O. U. Stephen, O. A. Oladeji, M. H Abdulhakeem, A. A. Micheal, A. 0. \& Friday, E. U. (2015). "Gastrointestinal helminth infections in a ruminant livestock farm in Abeokuta, South Western Nigeria”. Ann Res Rev Biol. 8(4): 1-8, https://doi.org/10.9734/arrb/2015/18812.

[28] Urquhart, G. M., Armour, J., Duncan, J.L., Dunn, A.M. \& Jennings, F. W. (1996). "Veterinary Parasitology", Volume. 28, Black Well Science, second Edition. 5-8.

[29] Yohanna, J. A., Dung, O. K., Adejoh, V. A. \& Pam, D. D (2019). "Prevalence of Helminth Parasites of Ruminants in Abattoir Market Jos, Jos South Local Government Area, Plateau State, Nigeria". Int J Biomed Health Sci. 15(2): 51-57.

[30] Yohanna, J.A., Maisae, R.D., Nwibari, B.M.W. Njoku, C.I. (2012). "Gastrointestinal helminths among slaughtered cattle at Jos Abattoir Plateau State". Nig J Parasitol. 33: 141-144. 